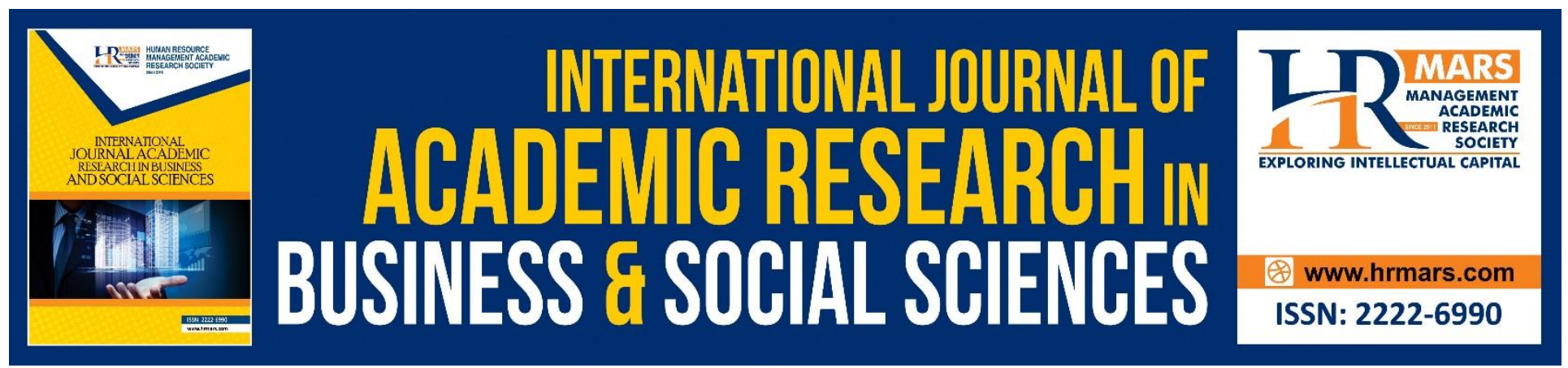

\title{
Effect of Career Management on Performance of Selected Manufacturing Firms in Enugu State
}

Maduagwu Nneka Esther, Ben Etim Udoh, Joy Ifeoma Enemuo

To Link this Article: http://dx.doi.org/10.6007/IJARBSS/v8-i11/4900

DOI: $10.6007 /$ IJARBSS/v8-i11/4900

Received: 26 Oct 2018, Revised: 13 Nov 2018, Accepted: 23 Nov 2018

Published Online: 26 Nov 2018

In-Text Citation: (Esther, Udoh, \& Enemuo, 2018)

To Cite this Article: Esther, M. N., Udoh, B. E., \& Enemuo, J. I. (2018). Effect of Career Management on Performance of Selected Manufacturing Firms in Enugu State. International Journal of Academic Research in Business and Social Sciences, 8(11), 285-299.

\section{Copyright: (C) 2018 The Author(s)}

Published by Human Resource Management Academic Research Society (www.hrmars.com)

This article is published under the Creative Commons Attribution (CC BY 4.0) license. Anyone may reproduce, distribute, translate and create derivative works of this article (for both commercial and non-commercial purposes), subject to full attribution to the original publication and authors. The full terms of this license may be seen at: http://creativecommons.org/licences/by/4.0/legalcode

Vol. 8, No. 11, 2018, Pg. 285 - 299

Full Terms \& Conditions of access and use can be found at http://hrmars.com/index.php/pages/detail/publication-ethics 


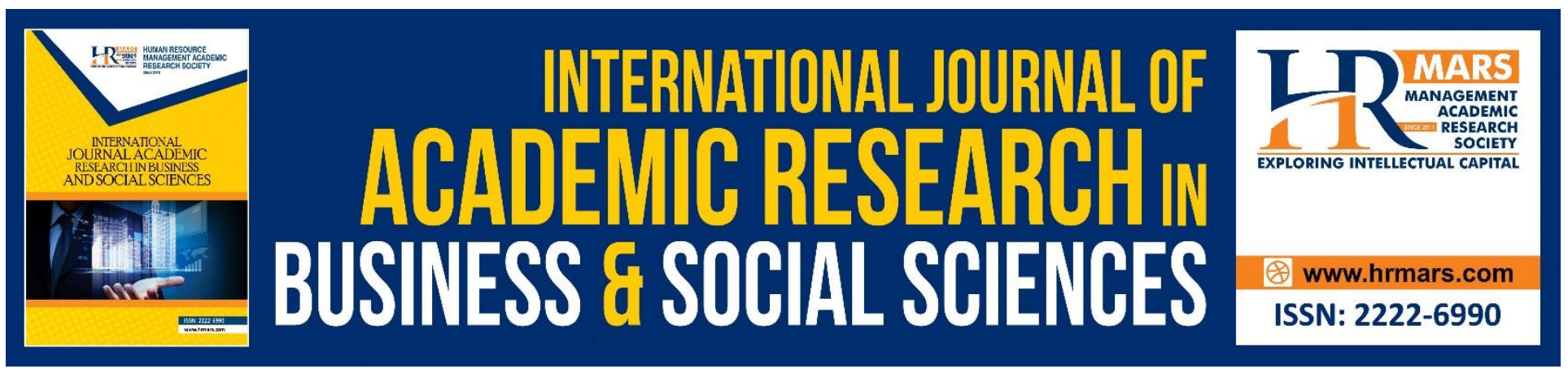

\title{
Effect of Career Management on Performance of Selected Manufacturing Firms in Enugu State
}

\author{
Maduagwu Nneka Esther Ph.D. \\ Department of Business Administration, Faculty of Management Science, Enugu state University of \\ Science and Technology (ESUT). \\ Email: Maduagwu.nneka@yahoo.com
}

Ben Etim Udoh Ph.D.

Department of Management, Faculty of Business Administration, University of Nigeria, Enugu Campus

Joy Ifeoma Enemuo Ph.D.

Department of Management, Faculty of Business Administration, University of Nigeria, Enugu Campus

\section{Abstract}

The study sought to determine the nature of the relationship between career planning and employee performance, ascertain the effects of career development on employee productivity in manufacturing firms in Enugu state and determine the extent of the relationship between Career path and goal attainment. The study had a population size of 2600, out of which a sample size of 347 was realised using Taro Yemene's formula at 5\% error tolerance and 95\% level of confidence. Instrument used for data collection was primarily questionnaire and interview. Out of 347 copies of the questionnaire that were distributed, 307 copies were returned while 40 were not returned. The descriptive survey research design was adopted for the study. The hypotheses were tested using Pearson product moment correlation coefficient and simple linear regression statistical tools. The findings indicate that there is a positive relationship between career planning and employee performance $(r=.944, P<.05)$. Career development significantly affects employee productivity in manufacturing firms in Enugu state $(r=0.879 ; F=1727.670 ; t=41.565 ; p<0.05)$. There is a positive relationship between Career path and goal attainment $(r=.955, P<.05)$. The study concluded that career management is concerned with the provision of opportunities for people to develop their abilities and their careers in order to ensure that the organization has the flow of talent it needs to satisfy their own aspirations.The study recommended that firms should constantly send their employees on training and development programme, so as to empower them with new skills to remedy job deficiency

Keywords: Career management, Performance; Manufacturing firms 
INTERNATIONAL JOURNAL OF ACADEMIC RESEARCH IN BUSINESS AND SOCIAL SCIENCES

Vol. 8, No. 11, Nov, 2018, E-ISSN: 2222-6990 @ 2018 HRMARS

\section{Introduction}

In today's competitive market, successful businesses regardless of size need employees who have the necessary knowledge and skills to make an effective contribution as drivers towards achieving a competitive edge. Therefore, vision of a competent, confident, loyal and valued workforce delivering high quality, person-centered services is rightly ambitious. Armstrong (2001) states and points out that today's dynamic environment requires continuous professional, managerial development and career management. Stakeholders should put in place, if not already available, a range of structures and processes to support the development of the workforce we need now and for the future. Pareek and Rao (1992) stress that training and development of employees should be seen as an investment, not a cost; and that bad performance, ignorance and low commitment to duty are very costly barriers in business. It is pointed out that the key to high levels of performance lies in having employees who are willing to work, are well managed, well led, well-motivated and are always re-skilling.

Dramatic changes in work organizations have created new 'career realities' that focus on the individual and require them to take responsibility for their own career development (Kidd, 2002). Organizations' increasingly incorporate self-development features into their career management interventions. In general, these initiatives emphasize job-related issues, reinforced by the use of competencies that focus on performance at work. However, individual career development goes beyond the assessment of strengths, weaknesses and training to improve job performance (McDowallandSilvester, 2006). Therefore, it is questionable if current practice is effective in supporting self-reliance in career management. Development activities should rather consider the competencies necessary for individual career management and the wider life areas in which these competencies develop (DeFillipiand, 1994).

The development of the capacity and capability of the organization's managers has a fundamental impact on efficiency, effectiveness, morale and profitability of an organization. High performing organizations increasingly pay close attention to the validity of their recruitment practices and are becoming equally vigilant about developing their employees in order to ensure they achieve optimum performance both in the present and the future. This is confirmed by Mwenebirinda (1998) who acknowledges that employee performance can be enhanced by training that addresses identified weaknesses.

All the techniques and strategies that individuals and organizations use to optimise careers and bring about career development can be referred to as career management (Bryant and Yarnold, 1995). The distinction between the individual and the organisation as active agents already suggests that career management can take place both within organisations and independent from organisations. Career management interventions are any efforts by organisations to provide individuals with specific experiences aimed at assisting them in managing their careers and meeting organisational requirements (Allred, Snow and Miles, 1996).

Career management has been described as "the process by which individuals collect information about values, interests and skill strengths and weaknesses (career exploration), identify a career goal and engage in strategies that increase the probability that career goals will be achieved" (Greenhaus, 1987, cited in Noe, 1996).

In today's fast-changing work- place, people need the skills and competencies to ensure future employability, and to manage new work and life realities.Organizations need flexible people, who can 
effectively manage change and adapt to new organizational directions. The key to achieving these goals, for both the individual and the organization, is career self-management(Gould and Penley, 1984).

\section{Statement of the Problem}

In today business environment, employees are becoming more career conscious than ever before. They are demanding more career advancement, personal growth, career progression and development. Organizations that fail to help employees in achieving their individual needs will lose their valuable employees. In the present work environment employees feel uncertain about their career advancement which automatically will drive them to look for where they can get passion, security and personal growth. However, in the organization's view, many employees that have being trained, leave the organization when they are needed most while some have remained stagnant with little evidence of career advancement.

Building a career is no longer about finding the right job and keeping it, but about making continual career choices in response to a rapidly changing job market. Thus, the knowledge economy demands a new approach to career management. The problem lies in quality and not quantity of manpower, as organizations fail on this path, there bound to be increase industrial accidents, lack of competitive edge, decrease in employees' engagement, decline in productivity and profitability. Thus the study focuses on effect of career management on organizational performance in selected manufacturing firms in Enugu, Nigeria.

\section{Objectives of the Study}

The main thrust of this study is effect of career management on organizational performance in selected manufacturing firms in Enugu, Nigeria.

The study has the following specific objectives:

i. To determine the nature of the relationship between career planning and employee performance

ii. To ascertain the effects of career developmenton employee productivity in manufacturing firms in Enugu state

iii. To determine the extent of the relationship between Career path and goal attainment.

\section{Research Questions}

For this study to accomplish the desired objectives, these research questions were formulated.

i. What is the nature of the relationship between career planning and employee performance?

iv. What are the effects of career development on employee productivity in manufacturing firms in Enugu state?

ii. To what extent is the relationship between Career path and goal attainment

\section{Research Hypotheses}

The following hypotheses were formulated for this study 
INTERNATIONAL JOURNAL OF ACADEMIC RESEARCH IN BUSINESS AND SOCIAL SCIENCES

Vol. 8, No. 11, Nov, 2018, E-ISSN: 2222-6990 @ 2018 HRMARS

i. There is a positive relationship between career planning and employee performance

ii. Career development significantly affects employee productivity in manufacturing firms in Enugu state

iii. There is a positive relationship between Career path and goal attainment.

\section{REVIEW OF RELATED LITERATURE}

\section{Conceptual Framework}

Career management can be defined as an ongoing process of preparing, implementing and monitoring career plans undertaken by the individual alone or in concert with the organization's career system (Schein. 2002).

Career management can be described as an "ongoing process" in which an "individual

i. gathers relevant information about himself/herself and the world of work:

ii. develops an accurate picture of his/her talents interests, values and preferred life

iii. style, as well as alternative occupations Jobs and organizations:

iv. develops realistic career goals based on this information and picture:

v. develops and implements a strategy designed to achieve the goals:

vi. obtains feedback regarding the effectiveness of the strategy and the relevance of the goals" (Greenhaus and Gallanan. 1994).

Career management may include activities that help individuals to develop and carry out career plans but the focus is on taking actions that increase the chance that the organisation anticipated HRM needs will he met

\section{Career Management as an Ongoing Process}

Career management can be described as an "ongoing process" in which an "individual

i. gathers relevant information about himself/herself and the world of work:

ii. develops an accurate picture of his/her talents interests, values and preferred life

iii. style, as well as alternative occupations Jobs and organizations:

iv. develops realistic career goals based on this information and picture:

v. develops and implements a strategy designed to achieve the goals:

vi. obtains feedback regarding the effectiveness of the strategy and the relevance of the goals" (Greenhaus and Gallanan. 2004:7).

\section{Career Planning and Career Management}

Career development can be described as a term that has an internal focus and refers to the way an individual views his/her career, but it has also an external focus that refers to the series of jobs and positions held by an individual. Understanding career development in an organization requires an examination of two processes: how individuals plan and implement their own career goals (career planning), and how organizations design and implement their career development programs (career management) (Bernardin and Russel, 1993). This process can be seen in figure 1. 


\section{Organizational career development}

Individual

Career Planning

subprocesses

- vuunarunar unvius

- - Occupational choice

- Organisational choice

- - Choice of job assignment

- Career self-development
Institutional

Career Management

- Recruitment and selection

- Human resource allocation

- Appraisal and evaluation

- Training and development

Figure: 1. A Model of Organizational Career Development

\section{Theoretical Framework}

\section{Self-concept Theory of Career Development}

Among the many theories of career choice and development, the theory by Superhas received much attention in the USA as well as in other parts of the world. Super $(1969,1980,1990)$ suggested that career choice and development is essentially a process of developing and implementing a person's self-concept. According to Super (1990), self-concept is a product of complex interactions among a number of factors, including physical and mental growth, personal experiences, and environmental characteristics and stimulation.

Building on Super's notion that self-concept theory was essentially a personal construct theory, Savickas (2002:155) took a constructivist perspective and postulated that "the process of career construction is essentially that of developing and implementing vocational self-concepts in work roles". A relatively stable self-concept should emerge in late adolescence to serve as a guide to career choice and adjustment. However, self-concept is not a static entity and it would continue to evolve as the person encounters new experience and progresses through the developmental stages. Life and work satisfaction is a continual process of implementing the evolving self-concept through work and other life roles. Super (1990) proposed a life stage developmental framework with the following stages: growth, exploration, establishment, maintenance (or management), and disengagement. In each stage one has to successfully manage the vocational developmental tasks that are socially expected of persons in the given chronological age range. For example, in the stage of exploration (ages around 15 to 24), an adolescent has to cope with the vocational developmental tasks of crystallization (a cognitive process involving an understanding of one's interests, skills, and values, and to pursue career goals consistent with that understanding), specification (making tentative and specific career choices), and implementation (taking steps to actualize career choices through engaging in training and job positions). Examples of vocational developmental tasks in each of the developmental life stages are described in Super (1990). Accordingly, the concept of "career 
INTERNATIONAL JOURNAL OF ACADEMIC RESEARCH IN BUSINESS AND SOCIAL SCIENCES Vol. 8, No. 11, Nov, 2018, E-ISSN: 2222-6990 @ 2018 HRMARS

maturity" was used to denote the degree that a person was able to fulfill the vocational developmental tasks required in each developmental stage. Partially due to the mixed results obtained in empirical research studies on career maturity, there have been suggestions to replace career maturity with the concept of adaptability (Herr, 1997; Savickas, 1997, 2002, 2005).

\section{Empirical Review}

Sarah (2004) conducted a study on career development and staff motivation in the banking industry: a case study of bank of Uganda. The objectives of the study were to assess career advancement after training, identify constraints to career advancement, assess the level of motivation among trained personnel, establish strategies to minimize constraints to career advancement and assess the effect of career advancement on motivation. The study revealed that among other things, low chances of promotion after training seem to point to the irrelevance of training to promotion. A marked lack of opportunities regarding career paths was revealed. The study revealed that although Bank of Uganda recognized skills and accomplishments after training. It was revealed, through the study, that the inflexible organizational structure, poor policies on promotion, favoritism and irrelevant training were responsible for lack of career advancement after training. The study identified setting clear and transparent policies on promotion and free and fair competition for promotion as a few of the strategies that could minimize constraints to career advancement. The study also revealed that career advancement had a highly significant effect on motivation. The study recommended that organizations should send their employee on training that will serve as motivation.

Nura(2003) conducted a study on the relationship between career management, andindividual performance. The main objective of this study is to examine the relationship between career management and individual performance. The three dimensions measured career management were organizational career management (ocm), career planning and career strategies. The study also examined which among the dimensions and factors are the most important in explaining individual performance; through the comparison among dimensions in career management, and the comparison among factors in organizational career management and career strategies.

The findings of the study indicated that OCM, career planning, and career strategies were correlated with individual performance. This study also revealed that the three factors under OCM namely career information, career development and career management policy were related with individual performance. All factors in career strategies namely the seeking career guidance, building network of contacts, maintaining career flexibility, self-presentation, and extended work involvement were also correlated with individual performance. This study found that career planning is the most influential dimension of career management that contributed to individual performance. Whilst career development is found to be the most essential factor under OCM that influences individual performance; maintaining career flexibility and building network of contact are factors under career strategies that found significant in explaining individual performance. The study recommended that organizations should have career counselling unit that will help employees on their career planning.

Zeb(2004)carried out a study on career development in a learning organization. The study established the fact that if the objectives of the two processes are merged together then a synergetic effect is 
created which enhances the pace of both the process. The theoretical framework of this study has taken career development as dependent variable, Organizational Development strategies is the Independent Variable. This study analyzes the reliance of the introduction of knowledge sharing strategy of OD on the individual capacity development. The main construct of this study is to see the significance of the correlation between the processes of career development and Organizational Development. The study concluded that the Learning Organizations context is more supportive to the process of career development as compared to the Conventional context. The management of both the organizations are undoubtedly clear about the positive contribution of the capacity development process to organization's benefit but the role performed by the management in these two different context is different from each other. The study recommended that employee should go in-house training that boost knowledge of their work.

Mirjam (2009) conducted a study on Organizational career management "How and to which degree do organizational factors affect perceived intra-organizational career opportunities. The findings indicated that demographic characteristics have no significant influence on how the employees at Statoil perceive their intra-organizational career opportunities, whereas organizational factors supervisory support and feedback, collegial climate, influence and control, and competency utilization and development all have a positive influence on perceived intra-organizational career opportunities. While competence utilization and development had the largest direct effect, a path analysis revealed that supervisory support and feedback has a significant indirect effect on the dependent variable through the other organizational factors. This means that employers who wish to retain their employees need to create the space and opportunities for employees' development. According to the findings, leaders need to recognize competency development as an investment in employee retention. The study recommended that organizations should design organisational career opportunities so as encourage employee to move on with their job.

\section{METHODOLOGY}

The study adopted research survey design. The populations of the study focuses three manufacturing firms Enugu State include Innoson Technical and industrial (674),Nigeria BreweriesNinth Mile Enugu (1018) and 7up Bottling company (908) which amount to 2600. A sample size was determine using Taro Yamane formular which amount to 347 while the instrument was validated using face to face content validity by giving the tool to academicians who made necessary corrections so that the instrument can measure what it ought to measure. The tools used for test of hypotheses were Simple Linear Regression and Pearson Product Moment Correlation Co-Efficient. The reliability of the instrument was obtained using Spearman ranking order Correlation Co-Efficient which amount to a coefficient of 0.692 indicating a High Internal Consistency of the Instrument.

\section{DISCUSSION OF RESULT}

The data obtained from the field were presented and analysed with descriptive statistics to provide answers to the research questions while the corresponding hypotheses were tried out with Simple linear regression and Pearson's Correlation at 0.05 alpha level.

To determine the nature of the relationship between career planning and employee performance 
INTERNATIONAL JOURNAL OF ACADEMIC RESEARCH IN BUSINESS AND SOCIAL SCIENCES Vol. 8, No. 11, Nov, 2018, E-ISSN: 2222-6990 (C) 2018 HRMARS

Table 1: Coded Responses on research on the nature of the relationship between career planning and employee performance

\begin{tabular}{|c|c|c|c|c|}
\hline \multirow[t]{2}{*}{ s/no } & \multirow[t]{2}{*}{ Questionnaire items } & $\begin{array}{l}\text { S.Agree } \\
\text { /Agree }\end{array}$ & $\begin{array}{l}\text { Disagree } \\
\text { /S.Disagree }\end{array}$ & \multirow[t]{2}{*}{ Total } \\
\hline & & Freq & Freq & \\
\hline 1 & $\begin{array}{l}\text { Career planning increase employee } \\
\text { morale in Nigeria manufacturing } \\
\text { sector }\end{array}$ & $\begin{array}{l}299 \\
(302.75)\end{array}$ & $\begin{array}{l}8 \\
(4.75)\end{array}$ & 307 \\
\hline 2 & $\begin{array}{l}\text { Employee turnover can be reduce } \\
\text { through career planning }\end{array}$ & $\begin{array}{c}304 \\
(302.75) \\
\end{array}$ & $\begin{array}{c}3 \\
(4.75) \\
\end{array}$ & 307 \\
\hline 3 & $\begin{array}{l}\text { Career planning motivates } \\
\text { employees to put in their best in } \\
\text { their job }\end{array}$ & $\begin{array}{c}305 \\
(302.75)\end{array}$ & $\begin{array}{c}2 \\
(4.75)\end{array}$ & 307 \\
\hline \multirow[t]{2}{*}{4} & $\begin{array}{l}\text { Careerplanning significantly affect } \\
\text { performance of the Nigerian } \\
\text { manufacturing sector }\end{array}$ & $\begin{array}{c}303 \\
(302.75)\end{array}$ & $\begin{array}{c}4 \\
(4.75)\end{array}$ & 307 \\
\hline & TOTAL & $\begin{array}{c}1211 \\
(99 \%)\end{array}$ & $\begin{array}{c}12 \\
(1 \%)\end{array}$ & $1228(100)$ \\
\hline
\end{tabular}

\section{Source: Fieldwork 2017}

Table 1 shows that 1211(99\%) of the respondents indicated S.agree / agree, while $12(1 \%)$ indicated disagree/S.disagree. Based on the response from percentage analysis, it was conclueded that there is a positive relationship between career planning and employee performance

$\mathrm{Hi}$ : There is a positive relationship between career planning and employee performance

Table 2: Descriptive Statistics

\begin{tabular}{|l|r|r|r|}
\hline & \multicolumn{1}{|c|}{ Mean } & Std. Deviation & \multicolumn{1}{|c|}{ N } \\
\hline Career planning & 1.9130 & 1.24418 & 307 \\
\hline Employee performance & 1.9348 & 1.25596 & 307 \\
\hline
\end{tabular}

Table 3: Correlations

\begin{tabular}{|ll|r|l|}
\hline & $\begin{array}{c}\text { Career } \\
\text { planning }\end{array}$ & $\begin{array}{l}\text { Employee } \\
\text { performance }\end{array}$ \\
\hline Career planning & $\begin{array}{l}\text { Pearson } \\
\text { Correlation } \\
\text { Sig. (2-tailed) }\end{array}$ & 1 & $.944^{* *}$ \\
\hline
\end{tabular}


INTERNATIONAL JOURNAL OF ACADEMIC RESEARCH IN BUSINESS AND SOCIAL SCIENCES

Vol. 8, No. 11, Nov, 2018, E-ISSN: 2222-6990 @ 2018 HRMARS

Hi: There is a positive relationship between career planning and employee performance

Table 2: Descriptive Statistics

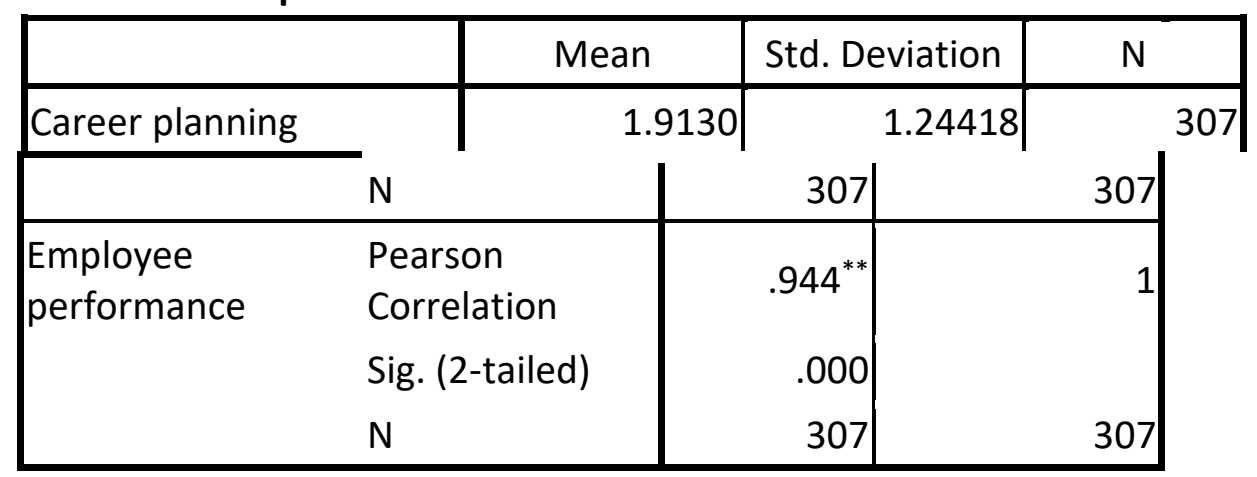

**. Correlation is significant at the 0.01 level (2-tailed).

Table (2) shows the descriptive statistics of the career planning and employee performance with a mean response of 1.9130 and std. deviation of 1.24418 for career planning and a mean response of 1.9348 and std. deviation of 1.25596 for employee performance and number of respondents (307). By careful observation of standard deviation values, there is not much difference in terms of the standard deviation scores. This implies that there is about the same variability of data points between the dependent and independent variables.

Table (3) is the Pearson correlation coefficient for career planning and employee performance. The correlation coefficient shows 0.944 . This value indicates that correlation is significant at 0.05 level (2tailed) and implies that there is a significant positive relationship between career planning and employee performance. $(r=.944)$. The computed correlations coefficient is greater than the table value of $r=.195$ with 305 degrees of freedom (df. $=n-2)$ at alpha level for a two-tailed test $(r=944$, $p<.05)$. However, since the computed $r=.944$, is greater than the table value of .195 we reject the null hypothesis and conclude that there is a significant relationship between bank career planning and employee performance. $(r=.944, \mathrm{P}<.05)$.

To ascertain the effects of career development on employee productivity in manufacturing firms in Enugu state 
INTERNATIONAL JOURNAL OF ACADEMIC RESEARCH IN BUSINESS AND SOCIAL SCIENCES Vol. 8, No. 11, Nov, 2018, E-ISSN: 2222-6990 (C) 2018 HRMARS

Table 3: Coded Responses of the effect of career development on employee productivity

\begin{tabular}{|c|c|c|c|c|}
\hline s/no & Questionnaire items & $\begin{array}{l}\text { S.Agree } \\
\text { /Agree }\end{array}$ & $\begin{array}{l}\text { Disagree } \\
\text { /S.Disagree }\end{array}$ & Total \\
\hline & & Freq & Freq & \\
\hline 1 & $\begin{array}{l}\begin{array}{l}\text { Employee that pass through } \\
\text { effective training } \\
\text { increase } \\
\text { organizational out }\end{array} \\
\end{array}$ & $\begin{array}{l}303 \\
(21) \\
\end{array}$ & $\begin{array}{c}4 \\
(2)\end{array}$ & 307 \\
\hline 2 & $\begin{array}{l}\text { Employee productivity can be } \\
\text { achieved through proper career } \\
\text { development }\end{array}$ & $\begin{array}{l}306 \\
(21)\end{array}$ & $\begin{array}{c}1 \\
(2)\end{array}$ & 307 \\
\hline 3 & $\begin{array}{l}\text { Acquiring a new skill on the job } \\
\text { improve employee productivity }\end{array}$ & $\begin{array}{l}305 \\
(21)\end{array}$ & $\begin{array}{c}2 \\
(2)\end{array}$ & 307 \\
\hline \multirow[t]{2}{*}{4} & $\begin{array}{l}\text { career development significantly } \\
\text { affect employee productivity in } \\
\text { manufacturing firms }\end{array}$ & $\begin{array}{c}307 \\
()\end{array}$ & - & 307 \\
\hline & TOTAL & $\begin{array}{l}1221 \\
(99 \%)\end{array}$ & $\begin{array}{c}7 \\
(1 \%)\end{array}$ & $1228(100)$ \\
\hline
\end{tabular}

\section{Source: Fieldwork 2017}

Table 3 shows that 1221(99\%) of the respondents indicated S.agree / agree, while 7 (1\%) indicated disagree/ S.disagree. Based on the response from percentage analysis it was concluded that career development significantly affects employee productivity in manufacturing firms in Enugu state

Hi: Career development significantly affects employee productivity in manufacturing firms in Enugu state

Table 4 Model Summary

\begin{tabular}{|l|r|r|r|r|r|}
\hline $\begin{array}{l}\text { Mode } \\
\mathrm{I}\end{array}$ & $\mathrm{R}$ & $\mathrm{R}$ Square & $\begin{array}{c}\text { Adjusted R } \\
\text { Square }\end{array}$ & $\begin{array}{c}\text { Std. Error of } \\
\text { the Estimate }\end{array}$ & $\begin{array}{c}\text { Durbin- } \\
\text { Watson }\end{array}$ \\
\hline 1 & $.879^{\mathrm{a}}$ & .773 & .773 & .54352 & .161 \\
\hline
\end{tabular}
a. Predictors: (Constant), Career development

b. Dependent Variable: Employee productivity

Table 5ANOVA ${ }^{a}$

\begin{tabular}{|c|c|c|c|c|c|c|}
\hline \multicolumn{2}{|c|}{ Model } & $\begin{array}{l}\text { Sum of } \\
\text { Squares }\end{array}$ & $d f$ & $\begin{array}{l}\text { Mean } \\
\text { Square }\end{array}$ & $F$ & Sig. \\
\hline \multirow{3}{*}{1} & Regression & 510.381 & 1 & 510.381 & 1727.670 & $.000^{b}$ \\
\hline & Residual & 149.776 & 306 & .295 & & \\
\hline & Total & 660.157 & 307 & & & \\
\hline
\end{tabular}

a. Dependent Variable: Employee productivity

b. Predictors: (Constant), Career development 
INTERNATIONAL JOURNAL OF ACADEMIC RESEARCH IN BUSINESS AND SOCIAL SCIENCES

Vol. 8, No. 11, Nov, 2018, E-ISSN: 2222-6990 @ 2018 HRMARS

Table 6 Coefficients ${ }^{\mathrm{a}}$

\begin{tabular}{|c|c|c|c|c|c|c|}
\hline \multirow{2}{*}{\multicolumn{2}{|c|}{ Model }} & \multicolumn{2}{|c|}{$\begin{array}{c}\text { Unstandardized } \\
\text { Coefficients }\end{array}$} & $\begin{array}{c}\text { Standardized } \\
\text { Coefficients }\end{array}$ & \multirow[t]{2}{*}{$\mathrm{t}$} & \multirow[t]{2}{*}{ Sig. } \\
\hline & & B & Std. Error & Beta & & \\
\hline \multirow{2}{*}{1} & (Constant) & -.448 & .059 & \multirow[b]{2}{*}{.879} & -7.571 & .000 \\
\hline & Career development & 1.329 & .032 & & 41.565 & .000 \\
\hline
\end{tabular}

a. Dependent Variable: Employee productivity

$$
\begin{array}{ll}
\mathrm{R} & =0.879 \\
\mathrm{R}^{2} & =0.773 \\
\mathrm{~F} & =1727.670 \\
\mathrm{~T} & =41.565 \\
\mathrm{DW} & =0.161
\end{array}
$$

\section{Interpretation:}

The regression sum of squares (510.381) is greater than the residual sum of squares (149.776), which indicates that more of the variation in the dependent variable is explained by the model. The significance value of the F statistics $(0.000)$ is less than 0.05 , which means that the variation explained by the model is not due to chance.

$\mathrm{R}$, the correlation coefficient which has a value of 0.879 , indicates that there is positive relationship between career development and employee productivity. R square, the coefficient of determination, shows that $77.3 \%$ of the variation in employee productivityis explained by the model.

With the linear regression model, the error of estimate is low, with a value of about 0.54352 . The Durbin Watson statistics of 0.161 , which is not more than 2 , indicates there is no auto correlation.

Career development coefficient of 0.879 , indicates a positive significance between career development and employee productivity, which is statistically significant (with $t=41.565$ ). Therefore, the null hypothesis should be rejected and the alternative hypothesis accordingly accepted. Thus career development significantly affects employee productivity in manufacturing firms in Enugu state 
INTERNATIONAL JOURNAL OF ACADEMIC RESEARCH IN BUSINESS AND SOCIAL SCIENCES Vol. 8, No. 11, Nov, 2018, E-ISSN: 2222-6990 (C) 2018 HRMARS

To determine the extent of the relationship between career path and goal attainment.

Table 7: Coded Responses on nature of the relationship between career path and goal attainment

\begin{tabular}{|c|c|c|c|c|}
\hline$. s / n o$ & Questionnaire items & $\begin{array}{l}\text { S.Agree } \\
\text { /Agree }\end{array}$ & $\begin{array}{l}\text { Disagree } \\
\text { /S.Disagree }\end{array}$ & Total \\
\hline & & Freq & Freq & \\
\hline 1 & $\begin{array}{l}\text { There is significant positive } \\
\text { relationship between career path } \\
\text { and goal attainment }\end{array}$ & $\begin{array}{c}301 \\
(304.25)\end{array}$ & $\begin{array}{c}6 \\
(3)\end{array}$ & 307 \\
\hline 2 & $\begin{array}{l}\text { Mentoring employee on a } \\
\text { particular career path improve } \\
\text { goal attainment }\end{array}$ & $\begin{array}{c}307 \\
(304.25)\end{array}$ & (3) & 307 \\
\hline 3 & $\begin{array}{l}\text { Goal attainment can be achieved } \\
\text { through proper coaching of } \\
\text { workers }\end{array}$ & $\begin{array}{c}304 \\
(304.25)\end{array}$ & $\begin{array}{l}3 \\
(3)\end{array}$ & 307 \\
\hline \multirow[t]{2}{*}{4} & $\begin{array}{l}\text { Effective goal attainment can be } \\
\text { promoted through career path }\end{array}$ & $\begin{array}{c}305 \\
(304.25)\end{array}$ & $\begin{array}{c}2 \\
(3)\end{array}$ & 307 \\
\hline & TOTAL & $1217(99 \%)$ & $12(1 \%)$ & $1228(100)$ \\
\hline
\end{tabular}

\section{Source: Fieldwork 2017}

Table 7 shows that $1217(99 \%)$ of the respondents indicated S. agree / agree, while 12(1\%) indicated disagree/ S. disagree. Based on the response from percentage analysis it was concluded that there is a positive relationship between Career path and goal attainment.

Table 8 :Descriptive Statistics

\begin{tabular}{|l|r|r|r|}
\hline & Mean & \multicolumn{1}{|c|}{$\begin{array}{c}\text { Std. } \\
\text { Deviation }\end{array}$} & \multicolumn{1}{|c|}{$\mathrm{N}$} \\
\hline $\begin{array}{l}\text { Career path } \\
\text { Goal }\end{array}$ & 1.8261 & 1.16043 & 307 \\
attainment & 1.9065 & 1.26713 & 307 \\
\hline
\end{tabular}

Table 9 : Correlations

\begin{tabular}{|ll|r|r|}
\hline & \multicolumn{1}{|c|}{$\begin{array}{c}\text { Career } \\
\text { path }\end{array}$} & Goal attainment \\
\hline Career path & $\begin{array}{l}\text { Pearson } \\
\text { Correlation }\end{array}$ & 1 & $.955^{* *}$ \\
& Sig. (2-tailed) & & \\
& $\mathrm{N}$ & 307 & .000 \\
& & 307 \\
\hline
\end{tabular}


Table 8 :Descriptive Statistics

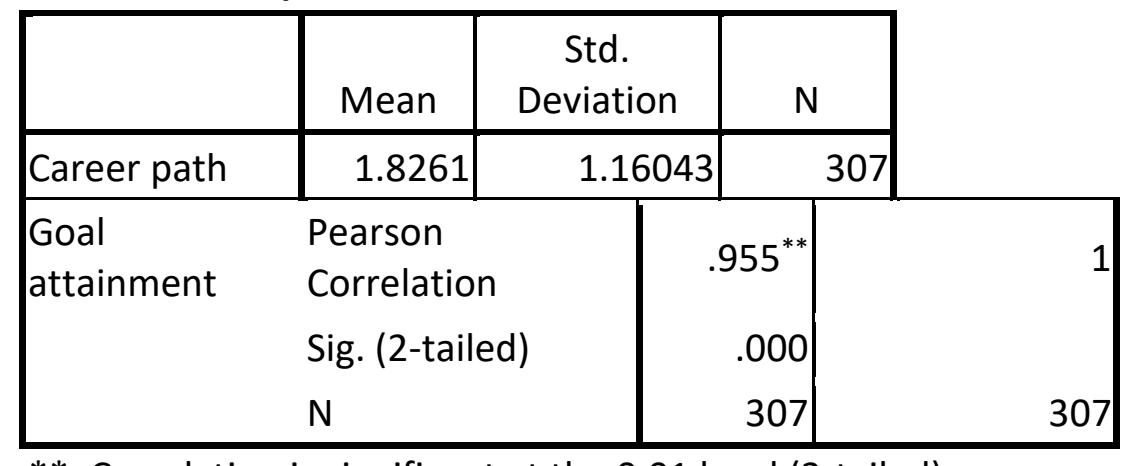

**. Correlation is significant at the 0.01 level (2-tailed)

.

Table (8) shows the descriptive statistics of the career path and goal attainment with a mean response of 1.8261 and std. deviation of 1.16043 for Career path and a mean response of 1.9065 and std. deviation of 1.26713 for goal attainment and number of respondents (460). By careful observation of standard deviation values, there is not much difference in terms of the standard deviation scores. This implies that there is about the same variability of data points between the dependent and independent variables.

Table (9) is the Pearson correlation coefficient for career path and goal attainment. The correlation coefficient shows 0.955 . This value indicates that correlation is significant at 0.05 level (2tailed) and implies that there is a significant positive relationship between career path and goal attainment. $(r=$ .955). The computed correlations coefficient is greater than the table value of $r=.195$ with 305 degrees of freedom (df. $=n-2)$ at alpha level for a two-tailed test $(r=.955, p<.05)$. However, since the computed $r=.955$, is greater than the table value of .195 we reject the null hypothesis and conclude that there is a positive relationship between career path and goal attainment $(r=.955$, $\mathrm{P}<$.05).

\section{Summary of Findings}

The findings at the end of this study include the following

i. There is a positive relationship between career planning and employee performance $(r=.944$, $\mathrm{P}<.05)$.

ii. Career development significantly affects employee productivity in manufacturing firms in Enugu state $(r=0.879 ; F=1727.670 ; t=41.565 ; p<0.05)$

iii. There is a positive relationship between Career path and goal attainment $(r=.955, P<.05)$.

\section{Conclusion}

The study concluded that career management is a combination of both organizational career management (OCM) and individual career management (ICM). Career management is concerned 
INTERNATIONAL JOURNAL OF ACADEMIC RESEARCH IN BUSINESS AND SOCIAL SCIENCES

Vol. 8, No. 11, Nov, 2018, E-ISSN: 2222-6990 @ 2018 HRMARS

with the provision of opportunities for people to develop their abilities and their careers in order to ensure that the organization has the flow of talent it needs to satisfy their own aspirations. It is about integrating the needs of the organization with the needs of the individual.

\section{Recommendations}

Based on the findings, the following recommendations were made

i. Firms should constantly send their employees on training and development programme, so as empower them with new skills to remedy job deficiency.

ii. Firms should design a career plan for their employeeswhich will increase employee morale, motivation and at same time reduce employee turnover.

iii. Firms should try an build a strong talent pool so as to place the most qualify staff at the right job.

Iv Firms should create a special unit guidance and counselling unit, so as to advice the employees on the right career path to follow

\section{REFERENCES}

Sverko, I., and Babarovic, T. (2006) The Validity of Holland's Theory in Croatia.Journal of Career Assessment, 14(4).

Green, P (2000) Motivating the Learner to Learn. Training Journal, Ely, 1(5)

Schein, E (2002) Organizational Culture and Leadership. 2nd Edition.Jossey-Bass, San Francisco

Greenhaus, J. H and. Gallanan.M (2004),AnInvestigation of the Role of Career Salience in Vocational Behavior, Journal of Vocational Behavior, 1(20).

Bernardin H. John, Russel J.E.A.(1993) Human Resource Management - An Experimental Approach. New York: McGraw Hill

Super, D. E., and Sverko, I. (1995)LifeRoles, Values and Careers: International Findings of Work Importance Study. San Francisco, CA: Jossey-Bass.

Super, D. W. (1969) Vocational Development Theory. The Counseling Psychologist, 1, 2-30.

Super, D. W. (1980)A life-span, life-space Approach to Career Development.Journal of Vocational Behavior, 16,(2).

Sanders, R. (2004) GeorgiaGain or GeorgiaLoss? The Great Experiment in State CivilSan Francisco, . 